\title{
The influence of phytogenic extracts on performance, nutrient digestibility, carcass characteristics, and gut microbial status in broiler chickens
}

\author{
D. Jamroz ${ }^{1}$ J. Orda ${ }^{1}$, C. Kamel ${ }^{2}$, A. Wiliczkiewicz ${ }^{1}$, T. Wertelecki ${ }^{1}$ \\ and J. Skorupińska ${ }^{1}$
}

\author{
${ }^{1}$ Department of Animal Nutrition and Feed Quality, Wrocław Agricultural University \\ Chetmońskiego 38D, 51-630 Wrocław, Poland \\ ${ }^{2}$ Axiss France SAS, Site D'Archamps-Immeuble ABC 1 \\ Archamps, Allee A, F-74160, France
}

(Received 2 September 2002; revised version 25 October 2002; accepted 15 July 2003)

\begin{abstract}
One thousand five hundred and forty Hybro HI-YR broilers were used in the study. One-day-old chickens were allocated to four groups; in the pen trial each group comprised 5 replications with 56 birds, in the digestibility trial there were 7 replications with 15 birds. The dietary treatments were as follows: unsupplemented control wheat-barley diet or the same diet supplemented with $10 \mathrm{ppm}$ avilamycin, 150 ppm or 300 ppm of plant extract (XT) containing capsaicin $(1.98 \mathrm{~g} / 100 \mathrm{~g})$, carvacrol $(4.95 \mathrm{~g} / 100 \mathrm{~g})$ and cinnamic aldehyde $(2.97 \mathrm{~g} / 100 \mathrm{~g})$. Performance was determined on days 21 and 48 . After slaughter the rectum content was collected for $E$. coli and Clostridium perfringens assay; slaughter yield and sensorial evaluation of breast and thigh muscles were performed on 16 birds per group. In the digestibility trial, on days 21 and 32 of life, after slaughter the apparent ileal digestibility of nutrients and amino acids was estimated on 28 birds per group. In comparison with the control group, up to day 21 of life the administration of feed antibiotic and $150 \mathrm{ppm}$ or $300 \mathrm{ppm}$ of plant extract enhanced body weight by 4.7, 5.4 and $8.1 \%(\mathrm{P}<0.01)$ and improved the feed conversion ratio by $5.8,3.1$ and $7.1 \%$, respectively $(\mathrm{P}<0.05)$. The mortality and culling rate was low (1.8-2.5\%). At 48 days of age, performance in groups as well as carcass characteristics were less diversified, only a slightly higher breast muscle share was obtained in the experimental groups. Sensorial characteristics of the breast and thigh meat were best in the group receiving $300 \mathrm{ppm}$ XT. In all supplemented groups the number of E. coli and Clostridium perfringens in rectal contents was significantly lower than in the control group; supplementation of the diet with 300 ppm XT and feed antibiotic had a similar effect on the number of evaluated microorganisms. Apparent ileal digestibility of nitrogen, nutrients, and amino acids, particularly of threonine, serine, asparagine, phenylalanine, histidine and lysine, in 21-day-old chickens was positively affected by XT supplementation. The coefficients of apparent ileal digestibility of nutrients in older birds (32-day-old) in groups fed diets with XT or feed antibiotic were similar.
\end{abstract}

KEYWORDS: chickens, phytogenic extracts, performance, ileal digestibility, amino acids, E. coli, C. perfringens, sensorial evaluation 


\section{INTRODUCTION}

Restrictions on the use of antibiotic growth promotors and other pharmaceutical enhancers in animal nutrition have opened avenues for the use of feed additives of natural origin, such as probiotics, prebiotics, or phytogenic substances (Horton et al., 1991; Damme, 1998; Basset, 2000; Hebeler et al., 2000). However, their modes of action, especially in poultry, are not fully understood and their performance benefits are not yet comparable with feed antibiotics (Kamel, 1999; Maidment et al., 1999). Herbs and spices are currently classified under EU legislation as flavours and appetising agents. The use of these additives is not without risk, either because their inclusion may reach harmful levels or because of their intrinsic ingredients. At high levels, some of them, such as tannins, haemaglutinins, saponins, cyanogenic substances or other components, may exert an antinutritional effect in animals.

The efficiency of biological activity of plant preparations depends on species, phytogenic substances, their stability and degree of purity, as well as on mode of action (Horton et al., 1991; Damme, 1998). Plant extracts are standardized products and are characterized in the literature by a number of activities. Antimicrobial, antiviral, antifungal activity, stimulation of appetite and secretion of endogenous enzymes, beneficial effect in the course of gastro-intestinal disorders and respiratory problems, antioxidant and immunostimulating properties of plant substances are only a few of those reported in humans and animals (Basset, 2000). Essential oils and oleoresins-cinnamaldehyde, capsaicin, carvacrol, piperin, allylisothiocyanates, thymol, menthol, and numerous other active agents, in various compositions constitute the basic ingredients of plant extract preparations.

In the present study the effect of supplementing a wheat- and barley-based diet with a plant extract preparation on ileal digestibility of nutrients, performance, carcass characteristics, meat quality, and rectal content bacteria count in broilers was evaluated. The plant extract contained capsaicin, cinnamaldehyde and carvacrol, and was postulated to affect appetite and digestion processes, to have a bacteriostatic effect, and to stimulate the growth of Lactobacillus spp.

\section{MATERIAL AND METHODS}

The experiments were performed on 1540 one-day-old Hybro HI-YR broiler chickens of average initial body weight $41.2 \mathrm{~g}$.

\section{Pen trial}

One thousand one hundred and twenty one-day-old chickens were randomly divided into four groups, each comprising five replicates with 56 birds (males/ 
females 1:1). Each replicate was kept in a separate-floor pen on wood-shaving litter. The temperature in the room was initially $29-30^{\circ} \mathrm{C}$ and was gradually reduced to $21^{\circ} \mathrm{C}$. The lighting program was $24 \mathrm{~h}$ light for the first 10 days, later $19 \mathrm{~h}$ light and $5 \mathrm{~h}$ darkness. The birds had free access to drinking water.

Chickens were fed diets of the composition shown in Table 1: unsupplemented negative control (I), or supplemented with 10 ppm avilamycin (II), 150 ppm (III), or $300 \mathrm{ppm}$ (IV) of XTRACT (XT). XT is a stabilized, standardized mixture containing carvacrol from oregano $(4.95 \mathrm{~g} / 100 \mathrm{~g})$, cinnamaldehyde from cinnamon $(2.97 \mathrm{~g} / 100 \mathrm{~g})$, and capsaicin from paprika $(1.98 \mathrm{~g} / 100 \mathrm{~g})$, coated with hydrogenated rapeseed oil on a gel matrix (produced by AXISS, France, SAS). Premixes added to diets contained only a coccidiostatic (Diclazuril) and were devoid of any other conventional feed supplements. The diets were available to the birds ad libitum (days 1-21, starter diet; days 22-48, grower diet).

TABLE 1

Composition of diets, $\mathrm{g} / \mathrm{kg}$

\begin{tabular}{|c|c|c|}
\hline \multirow{2}{*}{ Components } & \multicolumn{2}{|c|}{ Diets } \\
\hline & Starter & Grower \\
\hline Winter wheat v. Cobra & 274.0 & 310.5 \\
\hline Summer barley v. Brenda & 274.0 & 310.5 \\
\hline Soya oil & 70.0 & 62.4 \\
\hline Soyabean oilmeal & 339.0 & 274.0 \\
\hline Dicalcium phosphate & 12.9 & 13.1 \\
\hline Calcium bicarbonate & 14.7 & 15.1 \\
\hline Sodium chloride & 3.5 & 3.6 \\
\hline Premix DKA ${ }^{1}$ & 10.0 & 10.0 \\
\hline DL-methionine & 1.9 & 1.7 \\
\hline Crude protein ( $\mathrm{N} x$ 6.25) & 215.0 & 195.0 \\
\hline Crude fat & 83.3 & 75.8 \\
\hline Lysine & 11.68 & 10.15 \\
\hline Met + Cys & 9.73 & 8.99 \\
\hline Tryptophan & 2.75 & 2.26 \\
\hline Threonine & 8.30 & 7.41 \\
\hline $\mathrm{Ca}$ & 10.83 & 10.67 \\
\hline$P$ total & 6.30 & 6.25 \\
\hline$P$ available calculated ${ }^{3}$ & 3.51 & 3.49 \\
\hline Metabolizable energy $^{2} \mathrm{MJ} / \mathrm{kg}$ & 12.53 & 12.50 \\
\hline
\end{tabular}

${ }^{1}$ supplied per kg of diet (mg): retinylpalmitate 5.5 ; cholecalciferol 0.05 ; dl- $\alpha$-tocopherylacetate 20; menadione 3 ; thiamin 2.5 ; riboflavin 4.5 ; pyridoxine 4 ; cyanocobalamin 0.015 ; nicotinic acid 25 ; Ca-pantothenate 8; folic acid 1.2; choline chloride 450; $\mathrm{Mn} \mathrm{74;} \mathrm{Fe} \mathrm{30;} \mathrm{Zn} \mathrm{45;} \mathrm{Cu} 4$; Co 0.4; I 0.3; Diclazuril; DL-methionine 1.0

2,3 calculated from the chemical composition of the diets according to GfE Empfehlungen DLG (1999) 
Body weight and feed intake were measured on day 21 and 48; mortality was also recorded. At the end of the experiment, 8 males and 8 females from each dietary treatment were randomly selected and slaughtered after $12 \mathrm{~h}$ starvation. The content from the rectum was immediately collected from each bird for E. coli and Clostridium perfringens assay, then the birds were plucked, eviscerated and slaughter yields were determined. The sensorial characteristics of meat (colour, taste, smell, tenderness, juiciness) of the breast and thigh muscles were evaluated organoleptically on a 5-point scale by seven trained persons at the Institute of Animal Products Technology of the Agricultural University in Wrocław. The free water content was also determined in the samples of meat according to the method described by Baryłko-Pikielna (1975).

\section{Digestibility trial}

Four hundred twenty one-day-old male chickens were randomly divided to four dietary treatments, each comprising 7 replications of 15 chickens. Each replication was kept in a separate cage in a battery located in a room with the same standard environmental conditions as in the pen trial. The same diets as in the pen trial were given to the chickens ad libitum from day 1 to day 21 of life, followed by respective diets with $5 \mathrm{~g} / \mathrm{kg}$ of $\mathrm{Cr}_{2} \mathrm{O}_{3}$ added as a marker. On days 21 and 32 of life 4 chickens per replication ( 28 chickens per group) were killed, the gastrointestinal tract was dissected and the content of the ileum $(20 \mathrm{~cm}$ from the ileo-caecal junction) was collected for estimation of ileal digestibility of nutrients. The ileal contents were pooled for each replication within a group.

\section{Microbiological and chemical analysis}

One gram of fresh rectal digesta was mixed with $99 \mathrm{ml}$ of buffered peptone water and subsequent dilutions were prepared. Clostridium perfringens was cultured on TSC Agar Merck under anaerobic conditions at $+37^{\circ} \mathrm{C}$ for 24 h. Escherichia coli was cultured on Chromocult Coliform Agar (Merck) under the same conditions. The presence of E. coli was determined using KOVAC's preparation for indol estimation.

The ileal digesta samples prior to analysis were freeze-dried using an Edwards High Vacuum apparatus. The chemical composition of diets and ileal digesta was determined according to standard methods (AOAC, 1990). Phosphorus in diets was analyzed after previous mineralization by the ammonium vanadomolybdate method using a Specol 11 Carl Zeiss Jena spectrophotometer at a wave length of $470 \mathrm{~nm}$. Calcium in diets was determined by atomic absorption spectrophotometry using an AAS-3 EA-30 apparatus (Carl Zeiss, Jena). Amino acids in the diets and ileal digesta were determined by hydrolysis in $6 \mathrm{~N} \mathrm{HCl}$ for $22 \mathrm{~h}$ at $105^{\circ} \mathrm{C}$ according to the Moore- 
Stein method (1963) and separation of amino acids using a 231 XL Gilson Analyzer. For determination of sulphur amino acids, the samples were oxidized $\left(0^{\circ} \mathrm{C}, 24 \mathrm{~h}\right)$ with formic acid and $\mathrm{H}_{2} \mathrm{O}_{2}(9: 1)$ before $\mathrm{HCl}$ hydrolysis. The tryptophan content was measured colorimetrically at a wave length of $590 \mathrm{~nm}$ according to the Landry and Delhaye (1992) procedure after alkaline hydrolysis with $\mathrm{LiOH}\left(110^{\circ} \mathrm{C} ; 16 \mathrm{~h}\right)$ and 4-dimethyloaminobenzaldehyde (DMAB). Chromium oxide was determined according to Fenton and Fenton (1979). Gross energy density was determined with the use of a Parr KL-10 adiabatic oxygen bomb calorimeter (SP Precyzja, Bydgoszcz, Poland).

Data were evaluated statistically by one- or two-factorial analysis of variance using SAS ${ }^{\circledR}$ procedures. Differences between treatment means were tested according to Duncan's multiple range test (Duncan, 1955).

\section{RESULTS}

During the first 3 weeks of life, mortality and culling of crippled chickens was low and ranged between 1.8 and $2.5 \%$. On day 21 of life the body weight in groups fed diets supplemented with plant extract was 5.4\% (150 ppm) and 8.1\% $(300 \mathrm{ppm})$ higher in comparison with the negative control group $(\mathrm{P}<0.01)$. Body weight in the group fed the diet supplemented with feed antibiotic was $4.7 \%$ higher in comparison with the control (Table 2).

TABLE 2

Performance of chickens

\begin{tabular}{|c|c|c|c|c|c|c|}
\hline \multirow[b]{2}{*}{ Parameters } & \multicolumn{5}{|c|}{ Dietary treatment } & \multirow[b]{2}{*}{$\begin{array}{c}\text { Pooled } \\
\text { SEM }\end{array}$} \\
\hline & & $\begin{array}{c}\text { control } \\
\text { no } \\
\text { additive }\end{array}$ & $\begin{array}{c}\text { feed anti- } \\
\text { biotic } \\
10 \mathrm{ppm}\end{array}$ & $\begin{array}{c}\text { XT } \\
150 \mathrm{ppm}\end{array}$ & $\begin{array}{c}\text { XT } \\
300 \mathrm{ppm}\end{array}$ & \\
\hline Day 1-21 of life & Jo & & & & & \\
\hline Body weight $21 \mathrm{~d}, \mathrm{~g}$ & & $578^{\mathrm{A}}$ & $605^{\mathrm{AB}}$ & $608^{\mathrm{AB}}$ & $625^{\mathrm{B}}$ & 5.90 \\
\hline Daily weight gain, $\mathrm{g}^{1}$ & & $27.5^{\mathrm{A}}$ & $28.8^{\mathrm{AB}}$ & $28.9^{\mathrm{AB}}$ & $29.7^{\mathrm{B}}$ & 0.28 \\
\hline Feed conversion ratio, $\mathrm{kg} / \mathrm{kg}$ & & $1.56^{\mathrm{a}}$ & $1.47^{\mathrm{b}}$ & $1.49^{\mathrm{b}}$ & $1.44^{\mathrm{b}}$ & 0.01 \\
\hline \multicolumn{7}{|l|}{ Day $1-48$ of life } \\
\hline \multirow[t]{3}{*}{ Body weight 48 day, g } & $\sigma^{\pi}$ & 2558 & 2544 & 2597 & 2548 & 18.08 \\
\hline & q & 2049 & 2152 & 2134 & 2124 & 24.93 \\
\hline & d우 & 2303 & 2349 & 2365 & 2332 & 15.18 \\
\hline Daily weight gain, $\mathrm{g}^{1}$ & $\hat{O}+0$ & 48.1 & 48.9 & 49.2 & 48.3 & 0.31 \\
\hline Feed conversion ratio, $\mathrm{kg} / \mathrm{kg}$ & jo+ & 1.85 & 1.81 & 1.79 & 1.80 & 0.011 \\
\hline
\end{tabular}


The feed conversion ratio was $1.56 \mathrm{~kg} / \mathrm{kg}$ in the control group, in the group fed the diet supplemented with feed antibiotic it was $5.8 \%$ better, while in the groups fed the diets supplemented XT it was 3.1 (III) and 7.1\% (IV) better $(\mathrm{P}<0.05)$.

At 48 days of age, the body weight varied from 2309 to $2363 \mathrm{~g}$. Performance calculated for the entire experimental period was similar in groups fed diets supplemented with the feed antibiotic or plant extract and in the control group. Daily feed intake amounted on average to $72 \mathrm{~g} / \mathrm{bird}$, the feed conversion ratio was only slightly improved in the groups fed supplemented diets (1.80 in comparison with $1.85 \mathrm{~kg} / \mathrm{kg}$ in the control group, respectively).

The dressing percentage was similar in all groups ( $70.6 \%$ on average). Breast muscle shares in the experimental groups were 3.6-1.8\% higher than in the control group. The abdominal fat share in \% of LBW was significantly $(\mathrm{P}<0.05)$ lower in the group fed the diet supplemented with $300 \mathrm{ppm} \mathrm{XT}$, in the other groups these values ranged between $1.40-1.66 \%$ of body weight (Table 3 ).

TABLE 3

Slaughter yield, in \% of LBW and sensory evaluation of meat in 5 points scale ${ }^{1}$

\begin{tabular}{|c|c|c|c|c|c|c|}
\hline \multirow{2}{*}{\multicolumn{2}{|c|}{ Item }} & \multicolumn{4}{|c|}{ Dietary treatment } & \multirow{2}{*}{$\begin{array}{c}\text { Pooled } \\
\text { SEM }\end{array}$} \\
\hline & & $\begin{array}{c}\text { control } \\
\text { no additive }\end{array}$ & $\begin{array}{l}\text { feed antibiotic } \\
10 \mathrm{ppm}\end{array}$ & $\begin{array}{c}\text { XT } \\
150 \mathrm{ppm}\end{array}$ & $\begin{array}{c}\text { XT } \\
300 \mathrm{ppm}\end{array}$ & \\
\hline \multirow{2}{*}{\multicolumn{2}{|c|}{$\begin{array}{l}\text { Dressing } \\
\text { Breast muscle } \\
\qquad \text { (without skin) }\end{array}$}} & 71.4 & 70.5 & 70.5 & 70.2 & 0.30 \\
\hline & & 16.3 & 16.7 & 17.0 & 16.8 & 0.14 \\
\hline \multicolumn{2}{|c|}{ Liver } & 2.92 & 2.72 & 2.71 & 2.91 & 0.05 \\
\hline \multirow{2}{*}{\multicolumn{2}{|c|}{$\begin{array}{l}\text { Abdominal fat } \\
\text { Edible giblets (liver, } \\
\text { heart, gizzard) }\end{array}$}} & $1.66^{\mathrm{a}}$ & $1.40^{\mathrm{a}}$ & $1.40^{\mathrm{a}}$ & $0.97^{\mathrm{b}}$ & 0.07 \\
\hline & & 5.28 & 4.99 & 4.99 & 4.96 & 0.08 \\
\hline \multirow{2}{*}{ Colour } & breast & 4.17 & 4.00 & 4.16 & 4.31 & 0.09 \\
\hline & thigh & 4.28 & 4.05 & 4.40 & 4.36 & 0.09 \\
\hline \multirow{2}{*}{ Taste } & breast & 4.07 & 3.83 & 4.16 & 4.23 & 0.08 \\
\hline & thigh & 4.16 & 4.03 & 4.68 & 4.46 & 0.08 \\
\hline \multirow{2}{*}{ Smell } & breast & 4.05 & 3.98 & 4.13 & 4.13 & 0.09 \\
\hline & thigh & $4.10^{\mathrm{a}}$ & $4.03^{\mathrm{a}}$ & $4.49^{\mathrm{b}}$ & $4.33^{\mathrm{ab}}$ & 0.08 \\
\hline \multirow{2}{*}{ Tenderness } & breast & $3.86^{\mathrm{ab}}$ & $3.59^{\mathrm{a}}$ & $3.93^{\mathrm{ab}}$ & $4.05^{\mathrm{b}}$ & 0.08 \\
\hline & thigh & $4.02^{\mathrm{A}}$ & $4.00^{\mathrm{A}}$ & $4.50^{\mathrm{B}}$ & $4.11^{\mathrm{A}}$ & 0.07 \\
\hline \multirow{2}{*}{ Juiciness } & breast & 3.68 & 3.38 & 3.88 & 3.94 & 0.09 \\
\hline & thigh & $4.03^{\mathrm{a}}$ & $3.94^{\mathrm{Aa}}$ & $4.48^{\mathrm{Bb}}$ & $4.12^{\mathrm{a}}$ & 0.08 \\
\hline \multirow{2}{*}{$\begin{array}{l}\text { Free water, } \\
\quad \% \\
\end{array}$} & breast & $21.6^{\mathrm{A}}$ & $19.2^{\mathrm{B}}$ & $19.9^{\mathrm{C}}$ & $20.4^{\mathrm{C}}$ & 0.18 \\
\hline & thigh & $19.3^{\mathrm{A}}$ & $23.4^{\mathrm{C}}$ & $19.9^{\mathrm{AB}}$ & $21.6^{\mathrm{B}}$ & 0.31 \\
\hline
\end{tabular}

$\mathrm{a}_{\mathrm{a}, \mathrm{A}, \mathrm{B}, \mathrm{C}}$ means within a row with no common superscripts were significantly different at:

a,b $\mathrm{P}<0.05,{ }^{\mathrm{A}, \mathrm{B}} \mathrm{P}<0.001$

${ }^{1}$ there were no significant differences between males and females 
The sensorial characteristics of the breast and thigh meat of broilers were generally good, however, for some parameters (breast muscles) they were better in the groups fed diets supplemented with the plant extract (Table 3). In all groups the meat was well coloured, meat taste and smell in the XT groups were distinctly better than in control birds. Significantly higher evaluations were obtained for meat tenderness and juiciness in birds fed supplemented diets as compared with the control group and the free water content in muscles was lower in the former (Table 3).

In all supplemented groups, the E. coli and Clostridium perfringens counts $(\mathrm{CFU} / \mathrm{g})$ in rectal digesta were significantly lower than in the control group. Supplementation of diets with $300 \mathrm{ppm}$ XT affected the number of potentially pathogenic microorganisms similarly as the addition of the feed antibiotic (Table 4).

TABLE 4

Number of bacteria (CFU) in $1 \mathrm{~g}$ of rectal digesta in 48 day old chickens

\begin{tabular}{|c|c|c|c|c|c|c|}
\hline \multirow[b]{2}{*}{ Bacteria } & & \multicolumn{4}{|c|}{ Number of bacteria } & \multirow[b]{2}{*}{$\begin{array}{l}\text { Pooled } \\
\text { SEM }\end{array}$} \\
\hline & & $\begin{array}{c}\text { control } \\
\text { no additive }\end{array}$ & $\begin{array}{c}\text { feed } \\
\text { antibiotic } \\
10 \mathrm{ppm} \\
\end{array}$ & $\begin{array}{c}\text { XT } \\
150 \mathrm{ppm}\end{array}$ & $\begin{array}{c}\text { XT } \\
300 \text { ppm }\end{array}$ & \\
\hline $\begin{array}{l}\text { Escherichia } \\
\text { coli }\end{array}$ & $\begin{array}{l}\hat{0} \\
0 \\
+ \\
0 \\
0\end{array}$ & $\begin{array}{l}4.95 \times 10^{6} \\
4.35 \times 10^{6} \\
4.65 \times 10^{6 a}\end{array}$ & $\begin{array}{l}9.87 \times 10^{4} \\
1.29 \times 10^{5} \\
1.14 \times 10^{5 b}\end{array}$ & $\begin{array}{l}8.45 \times 10^{5} \\
4.65 \times 10^{5} \\
6.55 \times 10^{5 c}\end{array}$ & $\begin{array}{l}2.32 \times 10^{5} \\
8.09 \times 10^{4} \\
1.56 \times 10^{5 b}\end{array}$ & $\begin{array}{l}5.80 \times 10^{5} \\
5.70 \times 10^{5} \\
4.02 \times 10^{5}\end{array}$ \\
\hline $\begin{array}{l}\text { Clostridium } \\
\text { perfringens }\end{array}$ & $\begin{array}{l}\lambda \\
0 \\
+ \\
\lambda 0\end{array}$ & $\begin{array}{l}4.50 \times 10^{2} \\
7.36 \times 10^{3} \\
3.91 \times 10^{3 a}\end{array}$ & $\begin{array}{l}9.67 \times 10^{1} \\
1.00 \times 10^{2} \\
9.83 \times 10^{1 b}\end{array}$ & $\begin{array}{l}5.33 \times 10^{1} \\
5.75 \times 10^{3} \\
2.69 \times 10^{3 a}\end{array}$ & $\begin{array}{l}2.53 \times 10^{2} \\
1.83 \times 10^{2} \\
1.86 \times 10^{2 b}\end{array}$ & $\begin{array}{l}6.09 \times 10^{1} \\
3.65 \times 10^{2} \\
1.75 \times 10^{2}\end{array}$ \\
\hline
\end{tabular}

statistical calculations were done after $\log _{10}$ - transformation; ${ }^{\mathrm{a}, \mathrm{b}, \mathrm{A}, \mathrm{B}}$ means within a row with no common superscripts were significantly different at: ${ }^{\mathrm{a}, \mathrm{b}} \mathrm{P}<0.05,{ }^{\mathrm{A}, \mathrm{B}} \mathrm{P}<0.001$

There were no significant differences in apparent ileal digestibility of energy in 21-day old chickens (Table 5). Dry matter digestibility was similar for the control group and group supplemented with $150 \mathrm{ppm}$ XT; in the group supplemented with $300 \mathrm{ppm}$ XT it was $4.1 \%$ higher. Crude fat digestibility coefficients were significantly higher in groups fed diets supplemented with plant extract $(\mathrm{P}<0.05)$ in comparison with the control, however, relatively large standard deviations were noted. Apparent ileal digestibility of nitrogen was high and amounted in means to about $82 \%$, while the addition of $300 \mathrm{ppm}$ XT enhanced this parameter by $2.7 \%$ $(\mathrm{P}<0.05)$. 
TABLE 5

Apparent ileal gross energy, nutrients and amino acids digestibility in 21 day-old chickens, $\%$

\begin{tabular}{|c|c|c|c|c|c|}
\hline \multirow[b]{2}{*}{ Component } & \multicolumn{4}{|c|}{ Apparent ileal digestibility, $\%$} & \multirow{2}{*}{$\begin{array}{c}\text { Pooled } \\
\text { SEM }\end{array}$} \\
\hline & $\begin{array}{c}\text { control } \\
\text { no additive }\end{array}$ & $\begin{array}{c}\text { feed antibiotic } \\
10 \mathrm{ppm}\end{array}$ & $\begin{array}{c}\text { XT } \\
150 \mathrm{ppm}\end{array}$ & $\begin{array}{c}\text { XT } \\
300 \mathrm{ppm}\end{array}$ & \\
\hline Energy & 66.9 & 65.5 & 66.8 & 67.2 & 0.67 \\
\hline Dry matter & $65.9^{\mathrm{a}}$ & $62.9^{\mathrm{b}}$ & $65.6^{\mathrm{a}}$ & $68.5^{\mathrm{c}}$ & 0.70 \\
\hline Crude fat & $64.5^{\mathrm{ab}}$ & $55.6^{\mathrm{a}}$ & $68.1^{\mathrm{b}}$ & $74.2^{\mathrm{c}}$ & 2.79 \\
\hline Crude ash & $19.9^{\mathrm{a}}$ & $11.2^{\mathrm{b}}$ & $17.9^{\mathrm{ab}}$ & $29.7^{\mathrm{c}}$ & 2.33 \\
\hline Nitrogen & $82.5^{\mathrm{a}}$ & $81.9^{\mathrm{a}}$ & $82.7^{\mathrm{a}}$ & $84.7^{\mathrm{b}}$ & 0.36 \\
\hline Asp & $77.5^{\mathrm{a}}$ & $79.5^{\mathrm{ab}}$ & $80.5^{\mathrm{b}}$ & $81.8^{\mathrm{b}}$ & 0.52 \\
\hline Thr & $70.3^{\mathrm{a}}$ & $74.5^{\mathrm{ab}}$ & $75.0^{\mathrm{ab}}$ & $76.8^{\mathrm{b}}$ & 0.88 \\
\hline Ser & $79.2^{\mathrm{a}}$ & $80.8^{\mathrm{ab}}$ & $81.2^{\mathrm{ab}}$ & $83.8^{\mathrm{b}}$ & 0.88 \\
\hline Glu & $91.5^{\mathrm{a}}$ & $91.2^{\mathrm{a}}$ & $93.1^{\mathrm{b}}$ & $93.8^{\mathrm{b}}$ & 0.33 \\
\hline Pro & $91.5^{\mathrm{a}}$ & $84.3^{\mathrm{ab}}$ & $86.4^{\mathrm{b}}$ & $87.5^{\mathrm{b}}$ & 0.72 \\
\hline Met & $90.3^{\mathrm{a}}$ & $87.0^{\mathrm{b}}$ & $88.7^{\mathrm{ab}}$ & $89.9^{\mathrm{a}}$ & 0.46 \\
\hline Phe & $84.3^{\mathrm{a}}$ & $80.2^{\mathrm{b}}$ & $86.9^{\mathrm{ab}}$ & $87.2^{\mathrm{a}}$ & 1.06 \\
\hline Lys & $86.2^{\mathrm{a}}$ & $88.3^{\mathrm{ab}}$ & $87.0^{\mathrm{ab}}$ & $88.9^{b}$ & 0.43 \\
\hline Arg & $88.8^{\mathrm{ab}}$ & $90.6^{\mathrm{a}}$ & $91.3^{\mathrm{a}}$ & $87.6^{\mathrm{b}}$ & 0.50 \\
\hline Trp & $80.4^{\mathrm{a}}$ & $79.1^{\mathrm{ab}}$ & $75.7^{\mathrm{b}}$ & $84.5^{\mathrm{c}}$ & 0.88 \\
\hline
\end{tabular}

a,b,A,B means within a row with no common superscripts were significantly different at:

${ }^{\mathrm{a}, \mathrm{b}} \mathrm{P}<0.05,{ }^{\mathrm{A}, \mathrm{B}} \mathrm{P}<0.001$

the digestibility coefficients (\%) for Cys (78-82), Gly (77-80), Ala (80-85), Val (76-79), Ileu (7981), Leu (79-82), Tyr (74-77), His (86-90) were numerically but insignificantly higher in 300 ppm XT group

The apparent ileal digestibility of amino acids in 21-day old chickens (Table 5) was high (about $82 \%$ ), yet significantly higher for asparagine, threonine, serine, glutamic acid, and tryptophan in the group fed the diet with 300 ppm XT in comparison with the control group.

In older birds (32 days of life) the apparent ileal digestibility of energy was relatively higher (71.9-73.7\%) than in younger chickens, and similar in all groups (Table 6). Also the digestibility of dry matter, nitrogen and fat also was similar, however, a tendency towards better fat digestibility in group IV was noted. The coefficients of apparent ileal digestibility of total amino acids reached a mean of $83.3 \%$ and were only slightly higher than the values obtained in younger birds $(82.6 \%)$, however for some amino acids significant differences between groups were found. 
TABLE 6

Apparent ileal gross energy, nutrients and amino acids digestibility in 32 day old chickens, $\%$

\begin{tabular}{|c|c|c|c|c|c|}
\hline \multirow[b]{2}{*}{ Component } & \multicolumn{4}{|c|}{ Apparent ileal digestibility, $\%$} & \multirow[b]{2}{*}{$\begin{array}{r}\text { Poolec } \\
\text { SEM }\end{array}$} \\
\hline & $\begin{array}{c}\text { control } \\
\text { no additive }\end{array}$ & $\begin{array}{c}\text { feed antibiotic } \\
10 \mathrm{ppm}\end{array}$ & $\begin{array}{c}\text { XT } \\
150 \mathrm{ppm}\end{array}$ & $\begin{array}{c}\text { XT } \\
300 \mathrm{ppm}\end{array}$ & \\
\hline Energy & 73.5 & 72.0 & 71.9 & 72.6 & 0.67 \\
\hline Dry matter & 68.8 & 68.7 & 68.6 & 69.3 & 0.64 \\
\hline Crude fat & 59.4 & 58.7 & 58.9 & 63.2 & 1.70 \\
\hline Crude ash & 39.1 & 42.7 & 44.6 & 43.6 & 1.40 \\
\hline Nitrogen & 81.3 & 80.6 & 79.7 & 80.7 & 0.53 \\
\hline Ser & $76.3^{\mathrm{a}}$ & $81.8^{\mathrm{ab}}$ & $81.4^{\mathrm{ab}}$ & $83.2^{\mathrm{b}}$ & 1.04 \\
\hline Glu & $94.2^{\mathrm{a}}$ & $93.1^{\mathrm{ab}}$ & $92.0^{\mathrm{b}}$ & $92.6^{\mathrm{b}}$ & 0.27 \\
\hline Ala & $78.9^{\mathrm{a}}$ & $74.4^{\mathrm{ab}}$ & $71.1^{\mathrm{b}}$ & $73.0^{\mathrm{ab}}$ & 1.08 \\
\hline Met & $83.8^{\mathrm{a}}$ & $84.5^{\mathrm{ab}}$ & $83.6^{\mathrm{a}}$ & $85.1^{\mathrm{b}}$ & 0.49 \\
\hline Leu & $86.6^{\mathrm{a}}$ & $85.4^{\mathrm{ab}}$ & $82.1^{\mathrm{b}}$ & $84.1^{\mathrm{ab}}$ & 0.62 \\
\hline Tyr & $84.4^{\mathrm{a}}$ & $80.5^{\mathrm{ab}}$ & $78.9^{\mathrm{b}}$ & $80.6^{\mathrm{ab}}$ & 0.76 \\
\hline Lys & 85.6 & 84.9 & 84.4 & 85.6 & 0.52 \\
\hline Arg & $86.1^{\mathrm{a}}$ & $89.1^{\mathrm{b}}$ & $89.5^{b}$ & $90.9^{\mathrm{b}}$ & 0.55 \\
\hline Trp & $83.6^{\mathrm{a}}$ & $83.7^{\mathrm{a}}$ & $79.6^{\mathrm{b}}$ & $81.4^{\mathrm{ab}}$ & 0.56 \\
\hline
\end{tabular}

$\mathrm{a}, \mathrm{b}, \mathrm{A}, \mathrm{B}$ means within a row with no common superscripts were significantly different at:

${ }^{\mathrm{a}, \mathrm{b}} \mathrm{P}<0.05,{ }^{\mathrm{A}, \mathrm{B}} \mathrm{P}<0.001$

the digestibility coefficients (\%) for Asp (80-81), Thr (71-75), Pro (88-91), Cys (76-78), Gly (8084), Val (80-83), Ileu (84-86), Phe (85-88), His (86-88) and Lys were insignificantly diversified between groups

\section{DISCUSSION}

Long-term use of feed antibiotics in broiler chickens has confirmed their efficacy, especially in sub-optimal field conditions. However, consumer health concerns have led the European Union (EU) to ban a number of the commercial feed antibiotics available on the market. Alternative feed additives that may improve performance and are effective and acceptable to EU consumers are urgently required.

Plant extracts based on capsaicin, cinnamaldehyde and carvacrol are used primarily in the pig and poultry feed industries as appetite and enzyme secretion stimulants (Lee et al., 1995; Kamel, 1999; Frost and Sullivan, 2000; Manzanillo et al., 2001), however, the number of scientific studies on their influence on animal performance is relatively small.

As it is the most widely used additive in the poultry feed industry, avilamycin at $10 \mathrm{ppm}$ was used as the feed antibiotic of choice to serve as a positive control in the present experiments. Comparison of the body weight of 21-day old broiler 
chickens pointed to similar growth-promoting effects exerted by the feed antibiotic and addition of $150 \mathrm{ppm}$ of plant extracts. The administration of $300 \mathrm{ppm}$ $\mathrm{XT}$, however, showed the best performance in the starter period by improving body weight by $8.1 \%$ and the feed conversion ratio by $7.1 \%$. Generally, all supplemented groups showed significantly improved feed conversion ratios.

In older birds, only tendencies towards a slightly higher body weight and slightly better feed utilization $(\mathrm{P}>0.05)$ in supplemented groups compared with the negative control were observed. The slightly worse performance indices seen in the feed antibiotic group in older birds are in agreement with results obtained in previously reported studies (Jamroz et al., 1992; Gollnisch and Halle, 2001).

Some beneficial effects of improvement of carcass quality were obtained by the dietary application of $300 \mathrm{ppm}$ of plant extracts. A tendency towards a greater share of breast muscle was noted in the chickens from the group fed the diet with $150 \mathrm{ppm}$ XT. The amount of abdominal fat in the carcass was radically reduced by feeding the diet enriched with $300 \mathrm{ppm}$ of plant extract, while the efficacy of 150 ppm XT was comparable with the group receiving the feed antibiotic. The favourable influence of plant-origin active substances on carcass quality has also been described by other authors (Horton et al., 1991; Rosiński et al., 2000; Gollnisch and Halle, 2001; Roth-Maier et al., 2001; Suto et al., 2002).

The tendency towards higher breast muscle share in the carcass may be related to the benefits seen in the apparent digestibility of specific amino acids. A tendency towards higher values of ileal total amino acid apparent digestibility coefficients, in particular lysine, was observed in chickens fed diets supplemented with plant extract or antibiotic. These values were similar to those estimated in young chickens by Jamroz et al. (2001). The improvement of the digestibility of some amino acids may be due to the antibiotic or to the presence of active substances of the plant extracts, mainly from paprika. Capsaicin has been shown to stimulate the activity of serine proteases, particularly trypsin and chymotrypsin, in laboratory animals (Platel and Srinivasan, 2000). The affinities of trypsin for basic amino acids (lysine and arginine) and of chymotrypsin for aromatic amino acids phenylalanine and tyrosine could explain the improved digestibilities of these amino acids. Lehmann et al. (1996) has shown a correlation between an increase in breast meat share and increased dietary availability of lysine and threonine in young turkey poults. In the present study, the increases in apparent ileal digestibility of lysine $(2.7 \%$ over control) and threonine (3.7\% over control) were also accompanied by a better breast muscle share in the body of chickens.

The sensorial characteristics of the meat from the breast and thigh muscles were the best in birds from groups fed diets supplemented with plant extract, especially with $300 \mathrm{ppm}$ XT. The stimulatory effect exerted by capsaicin and cinnamaldehyde on endogenous secretions and on digestion may result in a cumulative improvement of nutrient utilization and better quality indices. 
The active ingredients of the plant extract used in this experiment, particularly when it was used at a dose of $300 \mathrm{ppm}$, reduced the Clostridium perfringens and Escherichia coli counts in rectal contents to an equal degree as avilamycin. While the control of pathogenic intestinal microflora by direct antimicrobial action of antibiotics has been confirmed in numerous investigations, the reduction of populations of these microbes by plant extracts may occur by another distinct pathway (Maidment et al., 1999; Hebeler et al., 2000). Previous studies in post-weaning pigs have shown that the inclusion of XT results in a significant increase of Lactobacillus spp. counts in caecal contents (Manzanillo et al., 2001). In rats this has been linked with stimulation of Lactobacillus growth and lactic acid production in the presence of carvacrol, the active component of oregano. Lactobacillus spp. have been shown to act by a number of mechanisms, including competitive exclusion, to reduce the numbers of pathogenic bacteria in monogastric animals. This would support the conclusion that the feed antibiotic avilamycin and the phytogenic additives both reduced the number of gut pathogens, albeit by different pathways.

Dietary feed additives have been shown to work by a number of different mechanisms such as their ability to modify gut microflora and endogenous secretion of enzymes (Jakob et al., 2000). A reduction of the cholesterol level has been observed in poultry (Wenk et al., 1998), while antioxidant or anti-stress properties (Valenzuela,1995; Tschirch, 2000) have also been reported.

In our investigations the $300 \mathrm{ppm}$ dose of XT, in particular, improved the coefficients of fat and nitrogen digestibility in 3-week-old chickens. Comparable effects were obtained between the groups supplemented with $150 \mathrm{ppm}$ XT and the feed antibiotic at $10 \mathrm{ppm}$. The positive influence of capsaicin on fat metabolism in rats has also been shown in the investigations of Yoshioka et al. (2000).

\section{CONCLUSIONS}

From the results of the present study it can be concluded that certain parameters of performance, weight gain, feed conversion, carcass characteristics, gut microbial status as well as digestibility were improved in groups fed a diet supplemented with plant extracts over the group fed an unsupplemented diet. Furthermore, this improvement was comparable with the results of birds fed a diet supplemented with feed antibiotic.

The differences between groups, evoked by a feed additive and seen in this experiment, were distinctly larger in younger birds than in older ones, due to the immaturity of the digestive tract and microbial enzyme systems in the early growth period. The results from this study warrant further investigation to clarify the dose-dependent physiological modes of action of plant extracts and their biologically active substances in order to establish these as a sustainable alternative for poultry feeding systems. 


\section{REFERENCES}

AOAC., 1990. Official Methods of Analysis, Association of Official Analytical Chemists. $15^{\text {th }}$ Edition. Arlington, VA

Baryłko-Pikielna N., 1975. Outline of Sensory Analysis of Food (in Polish). WNT, Warszawa

Basset R., 2000. Oregano's positive impact on poultry production. World Poultry 16, 31-34

Damme K., 1998. Phytogene Verdauungsförderer - eine Alternative zu Fütterungsantibiotika. DGSMagazin, Geflügelmast 14,1-4

Duncan D.B., 1955. Multiple range and multiple F test. Biometrics 1, 1-42

Empfehlungen zur Energie-und Nährstoffversorgung der Legehennen und Masthühner Broiler, 1999. DLG-Verlag, Frankfurt, p.16

Fenton T.W., Fenton M., 1979. An improved procedure for the determination of chromic oxide in feed and faeces. Can. J. Anim. Sci. 59, 631-634

Frost C.K., Sullivan J.S., 2000. Market engineering and measurement research system. In: Strategic Analysis and Forecasts of the Essential Oils Market for Animal Health Feed Additives. Report No. 3876-3942

Gollnisch K., Halle I., 2001. Effecte von älterischen Ölen und Kräutern in der Tierernährung. Proceedings of Vitamin und Zusatzstoffe in der Ernährung von Mensch und Tier. 8. Symposium, Jena, pp.197-204

Hebeler D., Möller T., Ewe A., Kamphues J., Amtsberg G., 2000. Effect of an oregano-oil-supplement on chyme composition and microflora in the intestinal tract of weaned piglets. 6 . Tagung Schweine-und Geflügelernährung, Lutherstadt, pp. 64-66

Horton G.M.J., Fennell M.J., Prasad B.M., 1991. Effect of dietary garlic (Allium sativum) on performance, carcass composition and blood chemistry changes in broiler chickens. Can. J. Anim. Sci. 71, 939-942

Jakob S., Mosenthin R., Zabielski R., Pierzynowski S.G., 2000. The influence of different vegetable oils on the exocrine pancreatic secretion in piglets. 6. Tagung Schweine-und Geflügelernährung, Lutherstadt, pp.158-160

Jamroz D., Jakobsen K., Orda J.. Skorupińska J., Wiliczkiewicz A., 2001. Development of the gastrointestinal tract and digestibility of dietary fibre and amino acids in young chickens, ducks and geese fed diets containing high amounts of barley. Comp. Biochem. Physiol. 130, 643-652

Jamroz D., Schleicher A., Wiliczkiewicz A., Skorupińska J., 1992. Effect of feed antibiotics on blood morphotic and mineral components and meat quality of broiler chickens (in Polish). Rocz. Nauk. Zoot. 19 (1), 149-165

Kamel C., 1999. Use of plant extracts in European pig diets. Feed Comp. 19, 23-27

Landry J., Delhaye S., 1992. Determination of tryptophan in feedstuffs - comparison of two methods of hydrolysis prior to HPLC analysis. J. Sci. Food Agr. 58, 438-441

Lee Y., Howard L.R., Villalon, B., 1995. Flavonoids and antioxidant activity of fresh pepper Capsaicum annum cultivars. J. Food Sci. 60, 473-476

Lehmann D., Pack M., Jeroch H., 1996. Responses of growing and finishing turkey toms to dietary lysine. Poultry Sci. 75, 711-718

Maidment D.C.J., Dembny Z., Harding C., 1999. A study on the antibiotic effect of garlic Allium sativum on Escherichia coli and Staphylococcus albus. Nutr. Food Sci. 4-5, 170-172

Manzanillo E.G., Baucells F., Kamel C., Morales J., Perez J.F., Gasa J., 2001. Effects of plant extracts on the performance and lower gut microflora of early weaned piglets. J. Anim. Sci. 79, Suppl. 1, 473 (Abstr).

Moore S., Stein W.H., 1963. Discussion of classic method of acid hydrolysis. Methods Enzymol. 6,819 
Platel K., Srinivasan K., 2000. Influence of dietary spices and their active principles on pancreatic digestive enzymes in albino rats. Nahrung 44, 42-46

Rosiński A., Wężyk S., Bielińska H., Elminowska-Wende G., 2000. Effect of herbal supplements in goose diets on body weight gains and quality of carcass and breast muscles. Rocz. Nauk. Zoot. $8,176-181$

Roth-Maier D., Maa $\beta$ N., Paulicks B., 2001. First results on the use of Echinacea-cobs Echinacea purpurea in animal feeding. Proceedings of 8 Symposium Vitamine und Zusatzstoffe in der Ernährung von Mensch und Tier, Jena, pp. 205-210

SAS ${ }^{\circledR}$ Procedures Guide. Ver. 6.3 ${ }^{\text {rd }}$ Edition. SAS Institute, Cary Inc. NY, 705

Suto Z., Kamel C., Horn P., 2002. The growth promoting effect of a natural plant based additive in broilers (in preparation - personal communication)

Tschirch H., 2000. The use of natural plant extracts as production enhancers in modern animal rearing practices. Zesz. Nauk. AR Wroclaw, Zoot. XXV, 376, 25-39

Valenzuela A.B.,1995. Natural antioxidants: a new perspective for the problem of oxidative rancidity of lipids. Biotechnology in the Feed Industry. Proceedings of Alltechs 11th Annual Symposium. Nottingham University Press, pp. 207-220

Wenk C., Scheeder M., Spleiss Ch., 1998. Sind Kräuter Allerheilsmittel? Schriftenreihe Inst. Nutztierwissenschaften ETH Zürich 18, 95-108

Yoshioka M., Matsuo T., Lim K., Tremblay A., Suzuki M., 2000. Effect of capsaicin on abdominal fat and serum free fatty acids in exercise-trained rats. Nutr. Res. 20, 1041-1045

\section{STRESZCZENIE}

Wpływ fitogennego ekstraktu na wyniki produkcyjne, strawność składników pokarmowych, jakość tuszki i stan mikrobiologiczny jelita u kurcząt w różnym wieku

Tysiąc pięćset czterdzieści kurcząt broilerów Hybro HI-YR przydzielono do czterech grup doświadczalnych. W doświadczeniu wzrostowym każda grupa składała się z 5 powtórzeń po 56 ptaków odchowywanych w boksach na ściółce, w doświadczeniu strawnościowym każda grupa składała się z 7 powtórzeń po 15 ptaków odchowywanych w klatkach. Przygotowano następujące 4 diety: kontrolna pszennno-jęczmienna bez dodatków, taka sama dieta $\mathrm{z}$ dodatkiem: $10 \mathrm{ppm}$ avilamycyny lub 150 ppm albo 300 ppm ekstraktu roślinnego (XT) zawierającego kapsaicynę (papryka), karwakrol (oregano) i aldehyd cynamonowy (cynamon) w ilości odpowiednio 1,98; 4,95 i 2,97 g/100 g preparatu. W doświadczeniu strawnościowym oznaczono pozorną strawność jelitową składników pokarmowych poubojowo w 21 i 32 dniu życia kurcząt. Wyniki odchowu na ściółce były rejestrowane w 21 i 48 dniu życia, a po uboju u 16 ptaków z każdej grupy określono liczebność E. coli i Clostridium perfringens w treści jelita grubego oraz wydajność rzeźną, cechy sensoryczne mięśnia piersiowego i uda oraz ilość wolnej wody w mięśniach. W 21 dniu życia dodatek do diety antybiotyku paszowego lub 150 ppm i 300 ppm XT spowodowały zwiększenie masy ciała o 4,7; 5,4 lub $8,1 \%(\mathrm{P}<0,05)$ i poprawę wykorzystania paszy o 5,$8 ; 3,1$ i $7,1 \%(\mathrm{P}<0,05)$ w porównaniu z grupa kontrolną. Śmiertelność i selekcja kurcząt była niska i wynosiła 1,8-2,5\%. W wieku 48 dni wyniki produkcyjne oraz wydajność rzeźna były podobne w grupach, jedynie we wszystkich grupach otrzymujących dodatki stwierdzono nieznacznie większy udział mięśni piersiowych w tuszce. Cechy sensoryczne mięsa były nieco lepsze u kurcząt z grup otrzymujących ekstrakt roślinny. 
W grupach z dodatkami stwierdzono nieco mniejszą niż w grupie kontrolnej liczebność E. coli i istotnie $(\mathrm{P}<0,05)$ mniejszą liczebność $C$. perfringens w treści jelita grubego. Dawka 300 ppm XT powodowała podobną zmianę w liczebności mikroorganizmów jak antybiotyk paszowy. Pozorna strawność jelitowa aminokwasów, tłuszczu i azotu u ptaków w wieku 21 dni była większa w grupach otrzymujących dietę uzupełnioną XT, szczególnie dotyczyło to treoniny, seryny, asparaginy, fenyloalaniny, histydyny i lizyny. Współczynniki strawności pozornej składników pokarmowych u starszych ptaków były zbliżone w grupach otrzymujących XT lub antybiotyk paszowy. 